\title{
Uji efektivitas ekstrak melati (Jasminum sambac) pada penyembuhan luka insisi kelinci (Oryctolagus cuniculus)
}

\author{
${ }^{1}$ Ni Luh G. L. Jayalandri \\ ${ }^{2}$ Edward Nangoy \\ ${ }^{2}$ Jimmy Posangi \\ ${ }^{2}$ Robert A. Bara
}

\author{
${ }^{1}$ Kandidat Skripsi Fakultas Kedokteran Universitas Sam Ratulangi Manado \\ ${ }^{2}$ Bagian Farmakologi dan Terapi Fakultas Kedokteran Universitas Sam Ratulangi Manado \\ Email: lingganjayalandri12173@yahoo.com
}

\begin{abstract}
Flowers and leaves of jasmine (Jasminum sambac) have chemical substances that contain phytoconstituents such as alkaloids, glycosides, saponins, terpenoids and flavonoids. Flavonoid, an antioxidant, plays some importnat roles in wound healing due to their antibacterial effect. This study aimed to determine the effectiveness of jasmine leaf extract on incision wound healing in rabbits. This was an experimental study using three rabbits as test subjects. Wounds of $0.3 \mathrm{~cm}$ depth, $5 \mathrm{~cm}$ length, and $0.5 \mathrm{~cm}$ widened at both ends of the wound were made on the right and left sides of the back. Incised wound on the left side was treated with jasmine leaf extract ointment meanwhile the wound on the right side was untreated and was covered only with sterile gauze. Wounds were observed for two weeks to evaluate the changes of macroscopical length. The results showed that wounds treated with jasmine leaf extract ointment shrank and their edges united with the surrounding tissues faster than the untreated wounds. Conclusion: Jasmine leaf extract ointment accelerated incised wound healing in rabbits.
\end{abstract}

Keywords : wound healing, incision wounds, jasmine leaves

\begin{abstract}
Abstrak: Bunga dan daun melati (Jasminum sambac) memiliki kandungan kimia yang berpotensi farmakologi seperti alkaloid, glycosid, saponin, terpenoid dan flavonoid. Flavonoid berpotensi sebagai antioksidan dan mempunyai kerja yang dibutuhkan dalam proses penyembuhan luka seperti antibakteri. Penelitian ini bertujuan untuk mengetahui efektivitas ekstrak daun melati pada penyembuhan luka insisi kelinci. Jenis penelitian ini eksperimental menggunakan tiga ekor kelinci sebagai hewan uji. Punggung kanan dan kiri kelinci diinsisi sedalam $0,3 \mathrm{~cm}$ dengan panjang $5 \mathrm{~cm}$ yang dilebarkan $0,5 \mathrm{~cm}$ pada kedua ujung sisi luka. Luka punggung kiri diberi salep ekstrak daun melati, luka punggung kanan tidak diberi perlakuan hanya ditutup kasa steril. Pengamatan selama dua minggu untuk melihat perubahan panjang luka secara makroskopik. Hasil penelitian mendapatkan bahwa luka yang diberi salep ekstrak daun melati lebih cepat mengecil serta memiliki permukaan luka yang rata dan menyatu dengan kulit sekitar dibandingkan luka yang tidak diberi salep ekstrak daun melati. Simpulan: Salep ekstrak daun melati memiliki efek untuk mempercepat penyembuhan luka insisi kelinci.
\end{abstract}

Kata kunci: penyembuhan luka, luka insisi, daun melati

Melati (Jasminum sambac) termasuk dalam keluarga Oleaceae pada kelas Magnoliopsida-Dicotyledons yang merupakan tanaman asli dari Asia Selatan dan Asia
Tenggara. Bunga dan daun dari tanaman ini memiliki kandungan kimia alkaloid, glycosid, saponin, terpenoid dan flavonoid yang sering digunakan sebagai bahan 
penelitian untuk menilai aktivitas farmakologinya. ${ }^{1}$ Bunga Jasminum sambac dikenal sejak lama sebagai bahan pengobatan tradisional untuk meringankan berbagai penyakit seperti kudis, asma, bisul dan nyeri sendi. ${ }^{2}$

Flavonoid berpotensi sebagai antioksidan dan mempunyai aktivitas yang dibutuhkan dalam proses penyembuhan luka seperti antibakteri. ${ }^{3}$ Penyembuhan luka merupakan suatu bentuk proses usaha untuk memperbaiki kerusakan yang terjadi. Secara alami penyembuhan luka akan mengalami fase inflamasi, proliferasi dan maturasi. $^{4}$

Penelitian ini bertujuan untuk mengetahui efek daun Jasminum sambac terhadap penyembuhan luka.

\section{METODE PENELITIAN}

Jenis penelitian ini ialah eksperimental yang dilaksanakanan di Laboratorium Farmakologi Fakultas Kedokteran Universitas Sam Ratulangi Manado. Subjek penelitian yaitu tiga ekor kelinci jantan dewasa dengan berat sekitar 1500-2000 g.

Luka insisi pada punggung kiri kelinci dibuat dengan scalpel bilah nomor 10 kemudian diberikan salep ekstrak daun melati 1 kali sehari pada sore hari selama 14 hari sedangkan luka pada punggung kanan hanya ditutup dengan kasa steril.

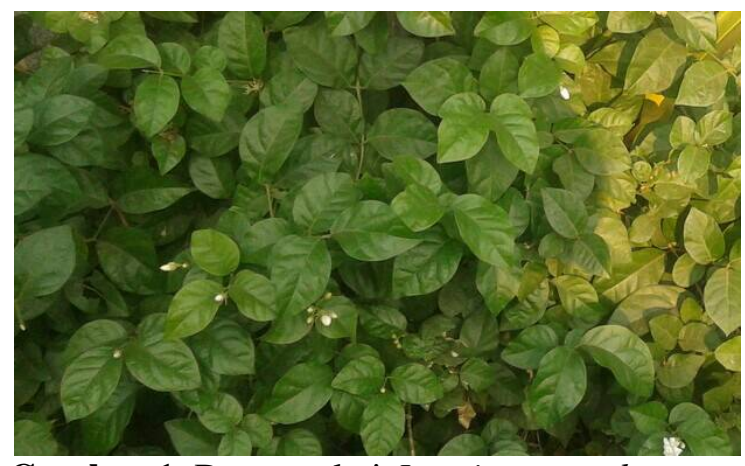

Gambar 1. Daun melati Jasminum sambac

\section{Pembuatan Salep Ekstrak Daun Melati}

Daun melati yang telah ditimbang dan dicuci dengan air mengalir diletakkan di dalam wadah kemudian dimasukkan ke dalam oven selama lebih dari 24 jam dengan suhu $40^{\circ} \mathrm{C}$, lalu digerus hingga halus dalam bentuk tepung. Tepung daun melati ditimbang dan dimaserasi dengan cara menambahkan pelarut etanol $80 \%$ dengan perbandingan (B:V) 1:4. Ekstrak dalam wadah tertutup disimpan pada temperatur ruangan (kamar) selama 5-7 hari sambil diaduk selama 15 menit setiap hari. Hasil maserasi disaring kemudian filtrat diuapkan dengan menggunakan rotary vacuum evaporator selama 3 jam dengan suhu $40^{\circ} \mathrm{C}$. Ekstrak daun melati dicampur hingga homogen dengan vaseline, perbandingan berat ekstrak daun melati 20 gram dan vaseline 20 gram (1:1).

\section{HASIL PENELITIAN}

Proses pemulihan luka insisi dengan mengamati permukaan, penyatuan tepi dan perubahan panjang luka secara makroskopik. Terdapat perbedaan pada luka insisi kelinci yang diberikan salep ekstrak daun melati dan luka yang tidak diberikan perlakuan. Proses penyembuhan luka lebih cepat terjadi pada luka yang diberikan salep ekstrak daun melati.

Luka yang diberikan salep ekstrak daun melati pada pemeriksaan makroskopik hari ke-3 (Gambar 2) menunjukkan tepi dan permukaan luka insisi lebih menyatu dan mengering; pada hari ke-7 panjang luka mulai berkurang; dan pada hari ke-14 (Gambar 3) luka menutup dengan dasar luka yang bersih dan rata dengan kulit sekitar dibandingkan dengan luka yang tidak diberikan salep ekstrak daun melati (Tabel 1).

\section{BAHASAN}

Sebelum pembuatan luka insisi, kelinci percobaan terlebih dahulu diberikan anestesi dengan menggunakan obat fentanil (0,3 mL/kg IM) dan midazolam (2 mg/kg IM). Kombinasi opioid dan benzodiazepin berlangsung sinergis dalam hal hipnosis dan depresi ventilasi serta memberikan anestesi bedah dengan relaksasi otot sangat baik selama 20-40 menit. ${ }^{5-7}$

Saat pembuatan luka insisi, terlihat adanya darah yang keluar akibat terputusnya pembuluh darah. Langkah pertama dari proses penyembuhan luka adalah hemostasis, terjadi karena trombosit 
berakumulasi pada tempat cedera dan melekat satu sama lain sehingga membentuk sumbatan trombosit. Kerusakan pembuluh darah mengakibatkan pemajanan serabut kolagen yang ada di bawahnya. Kontak antara trombosit dengan kolagen yang terpajan memicu pelepasan sejumlah faktor trombosit untuk menghasilkan fibrin yang dapat memperkuat sumbatan trombosit. $^{8,9}$

Pada hari ke-3 terjadi fase inflamasi dimana sel-sel dan protein yang berada dalam darah, komponen pembuluh darah (sel endotel) dan dalam jaringan konektif (fibroblas) mulai berproliferasi untuk membentuk jaringan granulasi dalam waktu 3-5 hari yang merupakan suatu tanda utama kesembuhan.

Pengamatan secara makroskopik pada hari ke-3 menunjukkan luka pada punggung kiri dan kanan kelinci masih terbuka tetapi luka yang diberikan salep ekstrak daun melati sudah sedikit menutup, tepi luka mulai kering, serta reaksi lokal terhadap jejas pada jaringan seperti rubor (merah), calor (hangat), tumor (bengkak) lebih jelas terlihat dibandingkan dengan luka tanpa perlakuan (Gambar 1).
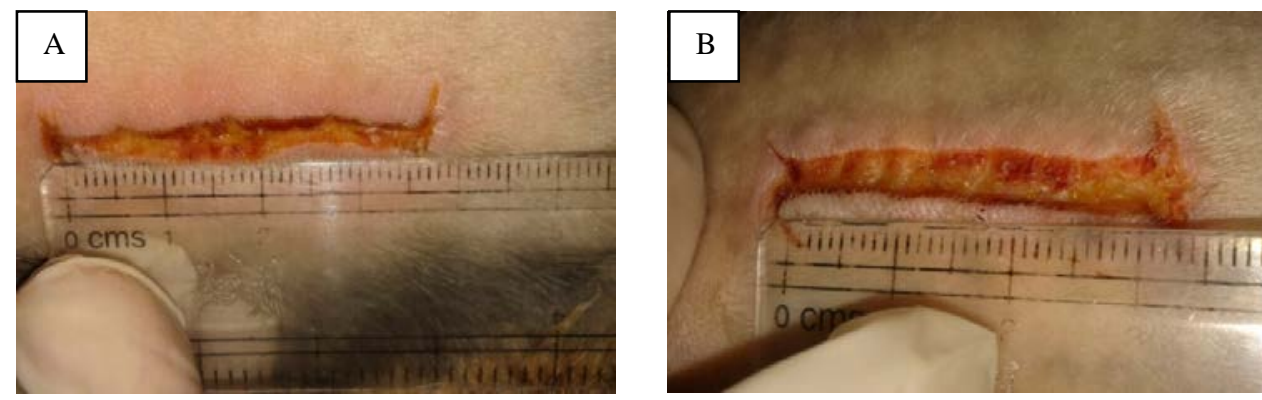

Gambar 2. Gambaran makroskopik penyembuhan luka insisi kelinci hari ke-3. A, Luka dengan perlakuan; B, luka tanpa perlakuan
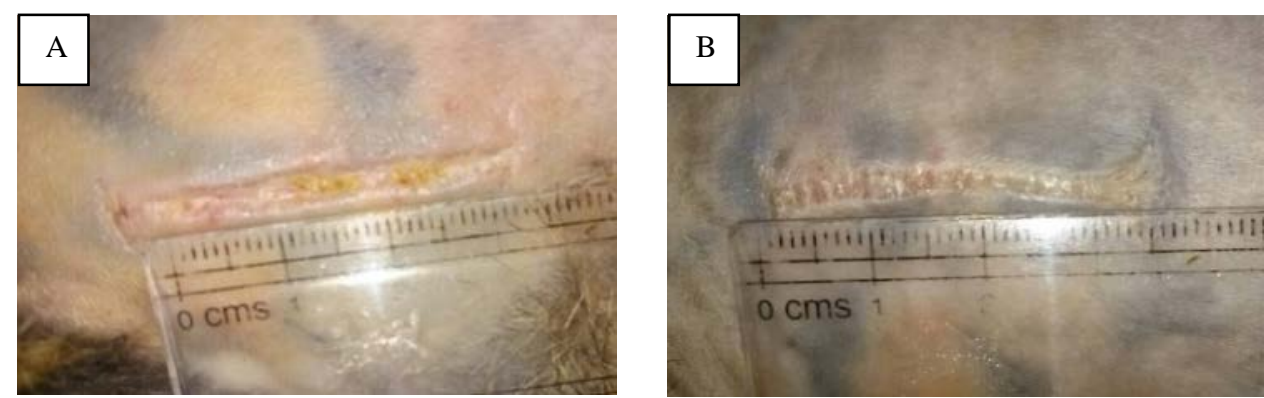

Gambar 2. Gambaran makroskopik penyembuhan luka insisi kelinci hari ke-14. A, Luka dengan perlakuan; B, luka tanpa perlakuan
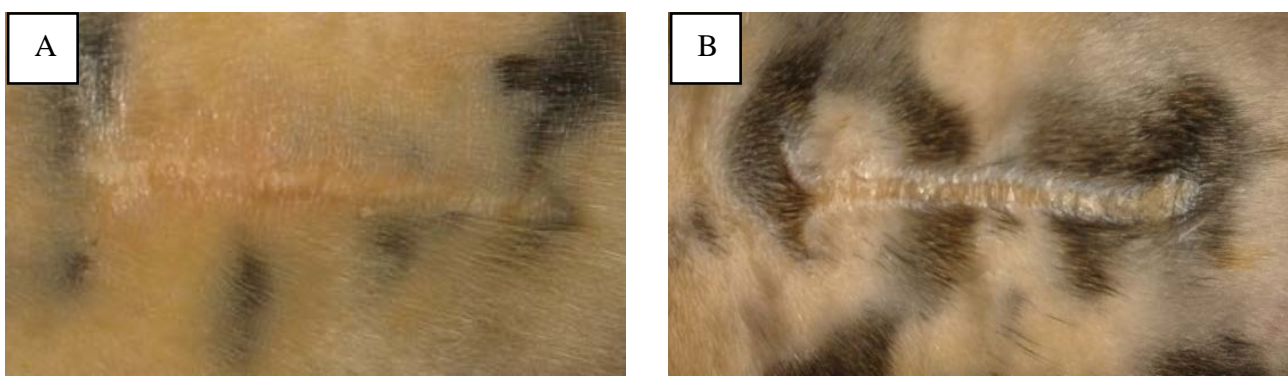

Gambar 3. Gambaran makroskopik penyembuhan luka insisi kelinci hari ke-18. A, Luka dengan perlakuan; B, luka tanpa perlakuan 
Jayalandri, Nangoy, Posangi, Bara: Uji efektivitas ekstrak...

Tabel 1. Perbandingan panjang luka pada penyembuhan luka insisi

\begin{tabular}{cccccccc}
\hline \multirow{2}{*}{ Hari ke- } & \multirow{2}{*}{ Tanggal } & \multicolumn{2}{c}{ Kelinci A1 } & \multicolumn{2}{c}{ Kelinci A2 } & \multicolumn{2}{c}{ Kelinci A3 } \\
\cline { 3 - 7 } & & Kiri & Kanan & Kiri & Kanan & Kiri & Kanan \\
\hline 1 & $05 / 1 / 2016$ & 5 & 5 & 5 & 5 & 5 & 5 \\
2 & $06 / 1 / 2016$ & 4,4 & 4,6 & 4,9 & 4,9 & 4,5 & 4,8 \\
3 & $07 / 1 / 2016$ & 3,7 & 3,8 & 4,8 & 4,9 & 3,8 & 4,4 \\
4 & $08 / 1 / 2016$ & 3,7 & 3,7 & 4,7 & 4,9 & 3,5 & 4,4 \\
5 & $09 / 1 / 2016$ & 3,6 & 3,7 & 4,7 & 4,8 & 3,4 & 4,4 \\
6 & $10 / 1 / 2016$ & 3,6 & 3,5 & 4,6 & 4,6 & 3,2 & 4,4 \\
7 & $11 / 1 / 2016$ & 3,2 & 3,4 & 4,5 & 4,6 & 3,1 & 4,4 \\
8 & $12 / 1 / 2016$ & 3,1 & 3,3 & 4,5 & 4,4 & 3 & 4,3 \\
9 & $13 / 1 / 2016$ & 2,8 & 3 & 4,3 & 4,3 & 2,4 & 4 \\
10 & $14 / 1 / 2016$ & 2,8 & 3 & 3,3 & 4,2 & 2,3 & 3,3 \\
11 & $15 / 1 / 2016$ & 2,7 & 2,9 & 3 & 4 & 1,8 & 3,3 \\
12 & $16 / 1 / 2016$ & 2,4 & 2,0 & 2,5 & 2 & 1 & 2,3 \\
13 & $17 / 1 / 2016$ & 2,3 & 1,8 & 0,5 & 0,7 & 0,6 & 1 \\
14 & $18 / 1 / 2016$ & 1,5 & 1 & 0,4 & 0,5 & 0,3 & 0,7 \\
\hline \multicolumn{2}{c}{ Kiri } & : Luka yang diberikan salep ekstrak daun melati & & \\
\multicolumn{2}{c}{ Kananyyyyyyyy} & $:$ Luka tanpa salep ekstrak daun melati & &
\end{tabular}

Hal tersebut di atas disebabkan karena daun melati mengandung flavonoid yang berperan sebagai antibakteri. Antibakteri dibutuhkan pada proses penyembuhan luka terutama pada fase destruktif yang berlangsung tumpang tindih dengan fase inflamasi di mana terjadi pembersihan terhadap jaringan mati atau yang mengalami devitalisasi dan bakteri oleh polimorf dan makrofag. ${ }^{10,11}$

Pada pengamatan makroskopik hari ke-7 didapatkan panjang luka pada punggung kiri dan kanan kelinci berkurang, hal ini dikarenakan pada fase proliferasi terjadi pembentukan barier permeabilitas (epitelisasi) dan pembentukan kembali jaringan dermis pada jaringan yang luka. Fase proliferasi dimulai segera setelah fase inflamasi yang berlangsung 4-6 hari. Ciriciri fase proliferasi adalah angiogenesis, epitalisasi, kontraksi luka dan deposit kolagen. Serabut kolagen merupakan substansi protein yang menambah tegangan permukaan dari luka, jumlah kolagen yang meningkat akan menyebabkan bertambahnya kekuatan regangan luka. ${ }^{10}$

Pemeriksaan makroskopik hari ke-14 memperlihatkan luka pada punggung kanan dan kiri kelinci sudah menutup tetapi belum sempurna (Gambar 3); hal ini dikarenakan berlangsungnya fase remodelling yang merupakan fase terpanjang dari penyembuhan luka di mana terjadi pematangan proses dari perbaikan yang sedang berlangsung pada jaringan granulasi yang membentuk lapisan epitel baru dan meningkatkan tegangan pada luka. Selain itu dikarenakan sel epitel kulit berdasarkan kemampuan regenerasi sel tubuh termasuk dalam sel labil di mana sel terus berproliferasi selama hidup menggantikan sel yang terus menerus rusak. Sel jaringan ikat yang penting dalam remodelling dan penyembuhan dari jaringan yang rusak ialah fibroblas. Fibroblas akan menghasilkan kolagen yang berperan sangat penting dalam penyembuhan luka karena kolagen meningkatkan faktor pertumbuhan dan mendorong proses fibroplasia serta proliferasi epidermis. Kolagen membutuhkan vitamin C untuk meningkatkan kekuatan regangan jaringan. Oksidasi vitamin $\mathrm{C}$ dengan kofaktor $\mathrm{Fe}^{2+}$ menyebabkan dikeluarkannya sejumlah anion radikal oksigen superoksida $\left(\mathrm{O}^{2-}\right)$ yang akan meningkatkan sintesis kolagen. Selain itu vitamin $\mathrm{C}$ berperan dalam memperkuat dinding pembuluh darah dan meningkatkan daya tahan tubuh melawan infeksi yang dibutuhkan dalam proses 
penyembuhan luka.

Pengamatan makroskopik penyembuhan luka perlakuan dilakukan sampai dengan hari ke-18 (Gambar 4). Luka memiliki permukaan yang lebih rata dan menyatu dengan kulit sekitar dibandingkan luka yang tidak diberikan perlakuan. Hal ini kemungkinan dapat disebabkan dari peran vitamin $\mathrm{C}$ pada kangkung dan wortel yang dikonsumsi kelinci percobaan; juga karena sifat antioksidan flavonoid pada ekstrak daun melati. ${ }^{10,12,13}$

\section{SIMPULAN}

Dari hasil penelitian dan bahasan dapat disimpulkan bahwa ekstrak daun melati berefek untuk mempercepat penyembuhan luka insisi kelinci.

\section{SARAN}

Perlu dilakukan penelitian lebih lanjut dengan peningkatan kadar dosis untuk melihat efektivitas pada penyembuhan luka serta menggunakan subjek penelitian lebih banyak agar mendapatkan hasil yang lebih akurat. Juga perlu dilakukan pemeriksaan secara mikroskopik.

\section{DAFTAR PUSTAKA}

1. Sabharwal S, Sudan S, Ranjan V. Jasminum sambac linn (motia): a review. International Journal of Pharmaceutical Research and BioScience. 2013;2(5):108-130.

2. Patil DA, Patil PS. Folk herbal medicine from some tehsils of Buldhana district (maharashtra) in India. Journal of Ecobiotechnology. 2011;3(2):04-10.

3. Rais IR. Isolation and determination of flavonoid content of (andrographis paniculata (burm.f.) ness) ethanolic herb extract. Pharmaciana. 2015;5(1):101-106.

4. Perdanakusuma DS. Anatomi fisiologi kulit dan penyembuhan luka. Airlangga University School of Medicine. 2007:5-7.

5. Gad SC. Animal models in toxicology (2nd ed). Boca Raton: CRC, 2007; p. 42437.

6. Departemen Farmakologi dan Terapeutik Fakultas Kedokteran Universitas Indonesia. Farmakologi dan terapi (5th ed). Jakarta: FKUI, 2007; p. 126222.

7. Rang HP, Ritter JM, Flower RJ. Rang and Dale's pharmacology (8th ed). England: Churchill Livingstone, 2015; p. 502-723.

8. Setiabudy RD. Hemostasis dan trombosis (3rd ed). Jakarta: FKUI, 2007; p. 114.

9. Greinacher A, Dhalback B, Eichinger S, Lillicrap D, et al. Thrombosis and haemostasis. Second Advanced Training Course in Thrombosis and Haemostasis; 2014 March 13-16; Cascais, Portugal: ISTH Press, c2014.

10.Morison MJ. Manajemen luka. Jakarta: EGC, 2012; p. 1-4.

11.Diegelmann RF, Evans MC. Wound healing: an overview of acute, fibrotic and delayed healing. Frontiers in Bioscience. 2004;9:283-9.

12.Reddy GA, Priyanka B, Saranya CH, Kumar C. Wound healing potential of Indian medicinal plants. International Journal of Pharmacy Review and Research. 2012;2:75-78.

13.Huy LA. Free radical, antioxidants in disease and health. International Journal of Biomedical Science. 2008;4(2):89-95. 